Article

\title{
Anatomizing the Institutional Arrangements of Urban Village Redevelopment: Case Studies in Guangzhou, China
}

\author{
Dinghuan Yuan ${ }^{1}$, Yung Yau ${ }^{2} * \mathbb{E}$, Haijun Bao ${ }^{3}$, Yongshen Liu ${ }^{4} \mathbb{C}$ and Ting Liu ${ }^{5}$ \\ 1 School of Public Administration and Emergency Management, Jinan University, 601 Huangpu Boulevard, \\ Tianhe District, Guangzhou 510632, China; dhyuan2-c@my.cityu.edu.hk \\ 2 Department of Public Policy, City University of Hong Kong, Tat Chee Avenue, Kowloon Tong, Kowloon, \\ Hong Kong 999077, China \\ 3 School of Public Administration, Zhejiang University of Finance and Economics, 18 Xueyuan Street, \\ Xiasha Higher Education Park, Hangzhou 310018, China; baohaijun@zufe.edu.cn \\ 4 Department of Public Policy, City University of Hong Kong, Tat Chee Avenue, Kowloon Tong, Kowloon, \\ Hong Kong 999077, China; yongshliu2-c@my.cityu.edu.hk \\ 5 College of Public Administration, Huazhong University of Science and Technology, Luoyu Road 1037, \\ Wuhan 430074, China; tingliu0727@hust.edu.cn \\ * Correspondence: y.yau@cityu.edu.hk
}

Received: 25 January 2019; Accepted: 10 June 2019; Published: 18 June 2019

\begin{abstract}
Given the increasing scarcity of urban land, the Chinese government has been initiating large-scale redevelopment of urban villages that are commonly regarded problematic for their low land use efficiencies and negative externalities. During this process, the emerging neo-urbanism in China demonstrates the heterogeneity of institutional arrangements, with different levels of transaction costs incurred. To explore the transaction costs incurred in different institutional arrangements of urban village redevelopment projects, this study anatomizes three projects in Guangzhou from the perspective of neo-institutional economics. The project duration and level of conflict are taken as two key variables to evaluate the efficiency and equality of the projects. With this research design, this study illustrates that institutional arrangements significantly affect the project outcomes. The conclusion suggests that the local and central governments alter the existing institutions with a view to lowering the transaction costs.
\end{abstract}

Keywords: urban villages; urban sprawl; institutional arrangements; transaction costs; social conflict; urban renewal; empowerment

\section{Introduction}

The rate of urbanization in China jumped from 36.2\% to 56.1\% during 2000-2015 [1]. Still there exist over one million villages within 662 cities in China. These villages are generally clusters of human settlements for the rural population. Among these villages, urban villages, also known as the "villages in the city," "villages amid the city," "villages encircled by the city," or chengzhongcun in Chinese, are a special product generated from the process of urbanization [2-4]. Because of the high demand for urban land use, the farmlands of villages located in the vicinity of cities were usually expropriated first due to relatively low compensation and transaction costs [5,6]. Rural land built up for settlement and reserved commercial land was left to the villagers. As a consequence, the remaining land and buildings in the villages were surrounded by modern urban skyscrapers. Under the urban-rural land system, the informality of urban villages consequently emerged [2,7]. To curb urban sprawl in Chinese cities, the local governments promote redevelopment of existing urban villages to optimize land use $[4,8-10]$. 
The governments' initiative goes in line with their ideology: "recycling of urban land as a measure to curtail urban sprawl" [11] (p. 350).

Previous research regarding urban villages conceptually pertains largely to the beneficial functions that they serve as social communities [12,13]. For instance, they provide low-rent living space for rural migrants and indirectly facilitate industrial and commercial development [5]. Simultaneously, this, in turn, increases the rental income for the indigenous residents whose farmland has been expropriated, which serves as a financial resource to support their livelihood [4]. Also, urban villages emerge as a kind of informal settlement $[2,7,10,14,15]$. To maximize the rental income, almost all the indigenous residents have built an additional floor upon their original houses in an unregulated context [5]. Those unapproved additional floors are regarded as illegal buildings according to the law. Without land use planning, the building plot ratios and site coverage are disorganized and disordered. The term "handshake buildings" or "kissing buildings" (wen lou) was coined to describe the distances of only several centimeters between buildings. The land use efficiency and intrinsic land value in the village is usually sub-optimal [15]. Apart from this, the living environment and social problems, such as declining infrastructure, crime, drugs, public health, fire hazards, and prostitution, often occur in the mixed societies of urban villages [16]. Despite these issues, the indigenous villagers are reluctant to improve the living environment, maintain buildings, or upgrade the surrounding infrastructure because of insecure property rights [2].

Various urban village renewal projects are initiated by local governments with the objective of reshaping the physical and social landscapes of the city so as to diminish negative externalities and improve land use efficiency. Yet, there are issues in the redevelopment of urban villages which are generated as well. For instance, conflict and resistance occur during assembly of scattered rural land for urban redevelopment [17]. Moreover, the redevelopment of urban villages results in social exclusion and gentrification [18]. In some cases, the affected residents are relocated far from their original location. The impoverished migrants can scarcely afford the increased rent to dwell in the place where they used to live. The enhanced living environment and infrastructure are seemingly enjoyed by only qualified and wealthy individuals. With increasing attention from social media and greater awareness of property rights, the transaction costs will become much higher if the government continues to adopt their original strategy.

Against this background, this study aims to examine if different institutional arrangements of village renewal projects bring about different project outcomes (e.g., longer/shorter project duration and higher/lower level of conflict). It attempts to utilize neo-institutional economic theory to anatomize and compare three cases with different approaches to redevelopment of urban village in Guangzhou. How institutional arrangements affect the outcomes of urban village renewal projects is the research question of this study. Guangzhou was chosen because it is a pilot city where innovative experiments are always performed to redevelop urban villages, with the objective of mitigating the transaction costs and achieving a new institutional equilibrium. It offers urban village renewal projects with different institutional settings for a meaningful empirical study. Both primary and secondary data was collected to achieve the goal of the research.

\section{Literature Review}

\subsection{Formal and Informal Institutions}

The theory of neo-institutional economics (NIE) is a useful explanatory tool for both individual and organizational behavior [19]. NIE is generally thought of as an extension to traditional neoclassical economics through the incorporation of transaction and information costs into economic analyses, and provision of an explanation for the creation of different institutional arrangements $[19,20]$. One of the key questions in NIE is which institution or institutional arrangement works best in resource allocation. Institutions are described as "the rules of the game in a society or, more formally, the humanly devised constraints that shape human interaction" [21] (p. 3). It is generally posited that institutions 
consist of both formal rules and informal rules [22]. Formal rules normally include political (and judicial) rules such as constitutions, regulations and laws, and economic rules and contracts [21]. The hierarchy of such rules defines constraints that range from general rules to particular specifications. However, informal rules generally comprise conventions, moral rules, and social rules, which originate from socially transmitted information and are invariably regarded as part of the cultural system [21]. Formal rules can complement informal constraints and increase their efficiency, while informal constraints can in turn modify, supplement, or extend formal rules [23].

For land use and development, we have institutional frameworks [24]. The function of the institutional framework is to restrict the choice set of actors by structuring human interaction [18]. One major role of this is to reduce uncertainty in society by establishing a stable structure. This exerts a great impact on the consequences of economic, social, and political performance through the consequences on the costs of exchange, transactions, transformation, and production [21,22]. In effect, the market overall is a mixed bag of institutions; some increase efficiency while some decrease it [21]. Despite the effective implementation of institutions largely contingent on the effectiveness of monitoring and severity of punishment, the latter makes them costly to implement [18]. Also, how well institutions solve the issues of coordination and production is primarily determined by three factors: (1) the motivation of the players (their utility function); (2) the complexity of the environment; and (3) the ability of the players to decipher and order the environment (measurement and enforcement) [21].

The next concept this study will elaborate on is "institutional equilibrium" which is regarded as:

A situation where given the bargaining strength of the players and the set of contractual bargains that made up total economic exchange, none of the players would find it advantageous to devote resources into restructuring the agreements. Note that such a situation does not imply that everyone is happy with the existing rules and contracts, but only that the relative costs and benefits of altering the game among the contracting parties do not make it worthwhile to do so [21] (p. 86).

Therefore, alterations in relative prices, as well as the ideas and ideologies that form people's perceptions, induce institutional change, though such process is incremental [21]. Institutional changes can be a result of changes in actors and practices but they can also be an outcome of social construction $[25,26]$.

Institutions or institutional frameworks do not necessarily fulfil their purposes [24,27]. The experience of past failures should be drawn upon so that changes will consist of generating organizational trials and eliminating organizational errors [21]. Accordingly, the institutional framework needs to be adjusted, including the rules, norms, and enforcement [28]. Also, because different constituent groups have different opportunity costs and bargaining power with the government, the representative body that reflects the interests of constituent groups emerges to facilitate exchange between parties [21]. When alterations in bargaining power take place, the contracts will be restructured as well. In sum, the relative costs alter the source of institutional change, and in turn create incentives to establish more efficient institutions [21].

\subsection{Institutional Framework of Rural Land Use System in China}

\subsubsection{Evolution of the Rural Land Use System in China}

As urban village redevelopment always involves land transformation from rural collectively owned land into state-owned land, it is necessary to elaborate the formal institutions regarding rural land use system in China first. Since the establishment of the People's Republic of China (PRC) in 1949, land has been redistributed from the feudal landlords to the peasants through "land reform." Property rights and land use rights were clearly possessed by farmers who had the rights to manage, sell, and rent their land according to the PRC Land Reform Law in 1950 [29]. Nevertheless, in the course of establishing an egalitarian society based on communist principles, China started to deny private land ownership [30]. In the 1960s, collective ownership of rural land was introduced when the people's commune activities were initiated [31,32]. Article 60 of the People's Commune further endorses this principle by stipulating that the land in the scope of production team is possessed by the production 
team, including private plots, private hilly land, rural built-up land (land for house plot), and so forth, in which all the land cannot be rented and sold [21,33].

In that document, nevertheless, it also stipulated that "the members" house above the land belongs to the members forever and they have the right to sell and rent it". The interesting institutional arrangement of separation of buildings from rural land has therefore been established in China since then. Also, since the collective land cannot be transferred in the market, local governments initiated several laws and regulations to restrict and prohibit the sale of rural housing to urban citizens [31]. In spite of this, the transfer of rural housing has never stopped since the 1960s because of the relatively lower price compared to the market [34]. Consequently, the term "small property housing" was coined to delineate these illegal transactions. In 1979, the land property rights evolved to the Household Contract Responsibility System, under which the land use rights of agricultural land, was allocated to the farmers based on family demography, but the land ownership still remains "collective" [35,36]. Therefore, land use rights are separated from land property rights on the collectively owned land. However, the land use rights on collectively owned land differ from the rights for state-owned land, generating the institutional discrimination for rural collectively owned land.

\subsubsection{Institutional Discrimination for Rural Land}

Institutional discrimination refers to "the unjust and discriminatory treatment of a group of individuals by formal organizations such as governments and corporations, financial institutions, public institutions and other societal entities" [37] (p. 140). Since the land reform in 1982, the Chinese government has adopted a dual land system [32,38]. The land in urban areas is state-owned whereas land in rural areas and urban fringe areas are collectively owned, except for the land designated as state-owned [29,39]. Nevertheless, the dual land institutional arrangement generates institutional discrimination that is demonstrated by the different land transfer rights. More specifically, the land use rights of state-owned land can be traded in the market, whereas the rights for collectively owned land cannot be traded as a commodity. The latter can only be sold and traded among villagers within land tenure by exchange of contract rights [40]. Therefore, the property rights of collectively owned land are incomplete in the urbanization process [41]. When any enterprise or individual needs land for construction, they must apply to use the state-owned land according to Article 43 of the Land Administration Law. Thus, the only valid way to use rural land for an urban purpose is to transform the collectively owned land into state-owned land in the first place [38]. Nevertheless, local governments retain the right to acquire collectively owned land for public interests [42]. Due to the ambitious definition of "public interests" in law, some projects for non-public urban usage (such as industrial, commercial, and residential projects) have been justified and implemented under the banner of urban redevelopment [43-45].

\subsection{Institutional Change: Rural Restructuring in Guangzhou}

Chinese villages have become the basic collective economic organizations for the rural economy and rural communities since 1949 [46]. One of the autonomous mass organizations is the "villagers' committee" (VC, cunmin weiyuanhui), whose role is to manage and administer the villages. It is a system of "democratic supervision," which primarily amounts to stressing transparency and accountability in the political life of the village [47]. After the reform and opening up, the economic development in Guangzhou has increased rapidly. The rapid urbanization and economic development have led to a great demand for the urban land use [48]. The influx of migrants has exacerbated the fierce competition for limited land resources. As a result, the majority of farmland in urban villages and some peri-urban villages has been expropriated by local governments in Guangzhou since the 1990s. Then the governments returned some of the land to village collectives, which was called "reserved commercial land" (ziliu jingji yongdi) and could be legally leased for non-farming purposes, such as for offices, factories, and storage [49]. Due to higher compensation and transaction costs, the remaining built-up rural land for settlement and reserved commercial land, was left to the villagers. To realize urbanization as soon as possible, the Guangzhou government has initiated the policy of "institutional 
restructuring first, renewal follow-up." Then a series of institutional restructuring occurred in the villages. Specifically, the withdrawal of village restructuring (checun gaizhi) began to be implemented in the villages of Guangzhou. The new institution of joint-stock companies (JSCs) was substituted for the original collective economic organizations. Only village members can hold shares of JSCs. Shares are distributed generally based on villagers' working experience (laodong gongling). Each individual could obtain between 11 and 40 shares. In some cases, when villages constructed buildings to lease with insufficient funds, then the shares were based on the contributions that the village members made. JSCs are responsible for leasing and managing their collective assets. The rapid development of the tertiary sector in Guangzhou offers them a precious opportunity to use the collective land to construct hotels, apartments, office buildings, and industrial buildings to gain rental income. The bonus that is distributed to each cooperative member hinges on the number of shares they hold. Another institutional change is the transformation of VCs into resident committees (RCs), since the villagers have become "registered residents" who can enjoy social security as citizens. Through such institutional change, JSCs are regarded as autonomous economic organizations and RCs as autonomous social organizations.

Villages can be divided into three types: those that are (a) located at the core of a city and have lost their farmland completely, (b) located in the suburban area and retain a small amount of farmland, and (c) located on the outskirts of a city and still retain a large amount of farmland [50]. Urban villages are generally of the first type. The deteriorating living environment and social issues occurring in urban villages are incompatible with images of an "international city" that the Guangzhou government aims to build. Besides, since urban villages are located in the dense population region, the high demand for urban land use is in conflict with the common inefficient land use in urban villages. To improve land use efficiency and the living environment, local governments have issued a series of policies to implement urban regeneration. One of these is the "three olds redevelopment" (sanjiu gaizao). "Three olds" refers to old towns, old industrial buildings, and old villages. This policy aims to regenerate the existing dilapidated villages by constructing formal high-rise residential and commercial buildings. The speed of the urban village renewal project was further expedited by the Asian Games held in Guangzhou in 2010. The Guangdong government held two rounds of public input to achieve public consensus and ensure a smooth regeneration process [51]. To mitigate potential conflicts during the urban village renewal project, the local governments instituted the policy of "one village, one policy" (yicun yice) in which different institutional arrangements are implemented in different villages, to explore suitable institutional arrangements that minimize the transaction costs and expedite the progress. Apart from this, the "open, fair, and equitable" principles are encouraged during the process as well. In the next sections, we will discuss three different institutional arrangements for implementing urban village renewal projects with three different real-life cases in Guangzhou.

\section{Research Design}

The study area is located in Guangzhou which is not only the center of the Pearl River Delta, but also the largest metropolis and the economic, political, and cultural center of Guangdong Province in southern China [52]. The city has a total land area of $7343.4 \mathrm{~km}^{2}$ [53]. At the end of 2018, the city's population was estimated around 15 million [54]. As a sub-provincial city, Guangzhou has direct jurisdiction over eleven districts, including Baiyun District, Conghua District, Haizhu District, Huadu District, Huangpu District, Liwan District, Nansha District, Panyu District, Tianhe District, Yuexiu District, and Zengcheng District. At the end of 2018, the overall urbanization rate of Guangzhou was $79.8 \%$ which is higher than most Chinese cities [54]. In the 1990s, the local governments started to design plans for the village renewal, but none of them was implemented within the following ten years. Beginning in 2006, plans to hold the 2010 Asian Games facilitated the speed of urban renewal development in Guangzhou, together with the increasing awareness of the need for heritage protection and the improvement of housing conditions [55]. In 2009, the government in Guangdong province issued a policy (Ordinance No. 78) as a guideline for the "three olds" redevelopment to improve land use efficiency. In response to this policy, the urban renewal projects of urban villages 
in Guangzhou were to be implemented with an ambitious plan to redevelop 138 urban villages by 2020 (Cheng 2012). In spite of this ambitious goal, only four urban villages-Liede, Yangji, Pazhou, and Linhe- had completed the renewal when the fieldwork was conducted from 1 May to 31 May 2017. Both primary and secondary data were collected.

To reiterate, the key research question for the current research is how institutional arrangements affect the outcomes of urban village renewal projects (e.g., project duration and conflict level). To answer this question, both primary and secondary data were collected. Primary data came from site visits and in-depth interviews with the affected villagers while the sources of secondary data included relevant official policy and planning documents, news reports, and commentaries. In the in-depth interviews, the interviewees were asked about the processes of the redevelopment projects in their urban villages. Interview questions included: (1) What were the main objectives of the redevelopment project? (2) What was the institutional arrangement for the implementation the project? (3) What were the funding sources for the project implementation? (4) What roles did the VC and government play in the redevelopment process? (5) When did the project initiate? (6) When did all affected households sign the contract? (7) What were the compensation and relocation policies for the project?

In addition, the interviewees were asked about the conflicts or confrontations during the implementation process and how these conflicts or confrontations were resolved. The questions included (1) Has there been any violent conflict during the redevelopment process, and if yes, how did the conflict arise? (2) Do you think what the main challenges were during the implementation of the urban village redevelopment? (3) How do the government and VC solve these challenges? At the end of interview, questions like "how do you feel about the redevelopment project" and "what were the main changes after the redevelopment" were asked. For each case study village, 3-5 interviewees were interviewed. As shown in Table 1, the interviewees included original villagers, government officials and non-villager renters. The collection of some information like the project duration necessitates the interviewees' memory recall. Nonetheless, the interviewees' memory might be vague. To improve the information accuracy and consistency, the authors cross-checked the recall answers from an interviewee against answers from other interviewees or also against the information publicly available. All the collected information is used to measure the key variable in this study and to provide evidence for illustrating the impacts of institutions exerting on the project outcome. The collected information was incorporated in the narrative describing the urban village redevelopment process in each case study. As for the secondary data, the official policy and planning documents (e.g., relocation policies and project briefs) were accessed in two ways. The first way was the retrieval of the materials from the websites of the relevant government bureaus. The second way was making formal applications to the bureaus concerned for "information disclosure" (xinxi gongkai) for academic research purposes. Besides, online data from various social media (e.g., Sina Weibo, Sina News, Xinhua News, Tencent News and Beijing Times) was employed to corroborate and supplement the data we collected in fieldwork.

The locations of the study sites (see Figure 1) are in the Tianhe and Yuexiu districts of Guangzhou, next to the new central business district (CBD). "In such dense districts, the push to redevelop the surrounding villages is much more urgent than in the other districts. Despite the guideline of "one village, one policy", the institutional arrangement of the renewal projects in the villages of Yangji and Pazhou are very similar. We thus chose Yangji as the case study to illustrate the institutional arrangement due to the limited space in the article. In this study, the key measure for evaluating redevelopment project efficiency is the project duration. This variable was measured from the date when the local government or VC publicly announced the initiation of the urban village renewal project to the date when all affected villagers agreed to sell their property rights to the local government or VC. 
Table 1. Basic information of interviewees.

\begin{tabular}{ccccc}
\hline Interview No. & Interviewee & Age & Gender & Role \\
\hline LD 01 & Mr. Xiao & 38 & Male & Government official \\
LD 02 & Mr. Li & 55 & Male & Original villager \\
LD 03 & Mrs. Liang & 58 & Female & Original villager \\
LH 01 & Mr. Lin & 48 & Male & Original villager \\
LH 02 & Mrs. Lin & 54 & Female & Original villager \\
LH 03 & Mr. He & 28 & Male & Original villager \\
LH 04 & Miss Wu & 35 & Female & Non-villager renter \\
YJ 01 & Mrs. Li & 41 & Female & Original villager \\
YJ 02 & Mr. Yao & 20 & Male & Original villager \\
YJ 03 & Mrs. Zhang & 32 & Female & Original villager \\
YJ 04 & Mr. Liang & 50 & Male & Original villager \\
YJ 05 & Mrs. Yao & 32 & Female & Original villager \\
\hline
\end{tabular}

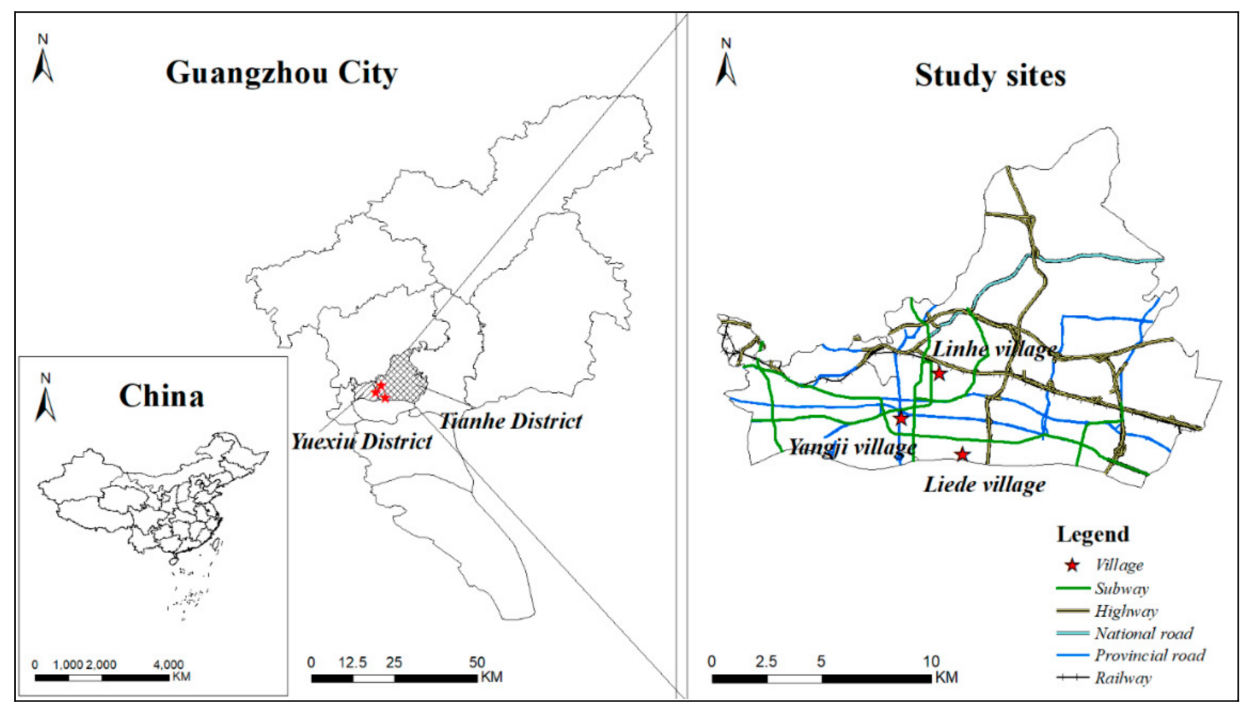

Figure 1. Locations of field sites.

\section{Findings}

\subsection{LEDC-Ledled Institutional Arrangement in Liede Village}

Liede is located in the south of the Tianhe district and has a history of over 900 years. Since 1994, all other farmland in this district has been expropriated by the government to build Zhujiang New Town. The institutional change in Liede Village began on 26 November 2002, when Liede abandoned the village committees and established the Liede Economic Development Company (LEDC). Accordingly, the status of the villagers has become "registered residents". Nevertheless, the dilapidated physical structures and lack of amenities in Liede Village are incompatible with the metropolitan image of Zhujiang New Town. Together with the need to construct the Liede Bridge that had to divide the village into the East and West parts and the need to hold the 2010 Asian Games, the urban village renewal project was ultimately initiated by the local government in February 2007.

To ensure the project was carried out smoothly, the government in the Tianhe district tried to explore a neoliberal approach in which market elements were allowed in the renewal process [56]. At the same time, the LEDC was empowered to implement the project [57]. From a decision-making perspective, this empowerment is a kind of bottom-up approach that enables villagers to design their own compensation and relocation scheme. This approach allows the affected villagers to benefit more from urban development projects, compared with a top-down approach [58]. This institutional arrangement can also decrease the transaction costs during the renewal process since the LEDC is 
similar to the representative body that knows the needs of the represented groups. This mechanism can save costs related to information collection. It is also a good approach to substitute for the previous method of bargaining with the householders one by one. Contrarily, the LEDC took an active role in encouraging the villagers' participation, pooling the funds for reconstruction, and relocating the affected villagers. More specifically, in March 2007, the LEDC held shareholders' representative meetings and several villagers' meetings to convey the renewal information and seek suggestions from affected villagers about compensation and relocation schemes. The schemes were finally determined by vote in several meetings of the stockholders' representatives. Finally, the government approved the scheme in June after the LEDC submitted it. Monetary compensation for illegal buildings was $\mathrm{RMB} 1000 / \mathrm{m}^{2}$. The in-kind relocation area was based on the original legal property area, namely "one-for-one compensation" (chaiyi buyi), meaning the relocated area is equal to the original legal areas. In practice, however, the calculation is more favored to the affected villagers so as to encourage their participation. The term "progressive re-housing system" (jiètì shì ānzhì fāngshì) was used to describe the following case: if the legal house is less than $i+1$ floors but more than $i$ floor, then then $i+1$ will be used in the calculation, where $i$ ranges from 1 to 3 . The villagers could then use the compensation, calculated at the rate of $\mathrm{RMB} 3500 / \mathrm{m}^{2}$, to buy the relocation plot. The area of the relocation plot is the difference between four floors of building plot minus the value calculated from the progressive re-housing system. From this institutional arrangement, we can see that the LEDC holds the real power to renew the dilapidated village with minimal interference from the local government. After the announcement of the demolition and relocation schemes for the affected residents, the residents voted in August to accept them, with $98.6 \%$ in favor, which is above the minimum consent rate of $90 \%$ for the project to become law. During the following month, $99.9 \%$ of the villagers made a contract with the LEDC about the unified compensation and relocation scheme. In the same month, the western part of the collectively-owned land, with an area of over $110,000 \mathrm{~m}^{2}$ in the village, was transformed into state-owned land with support by the government, and the land use rights were transferred to private developers, Fuli and Hejingtaifu, by public auction. With the involvement of market forces, the LEDC successfully pooled a total of RMB 4.6 billion to renew the village by themselves. The roles of various participating parties in the redevelopment process under the LEDC-led institutional arrangement of village renewal in Liede Village are graphically illustrated in Figure 2. Under such an institutional arrangement, the LEDC was fully empowered to initiate the redevelopment project. It managed all land requisition fees and designed the compensation and relocation policies pursuant to the government guidelines. The government served as a mediator in land transaction while the private developer gained the land use rights of the land concerned by paying the land transfer fees.

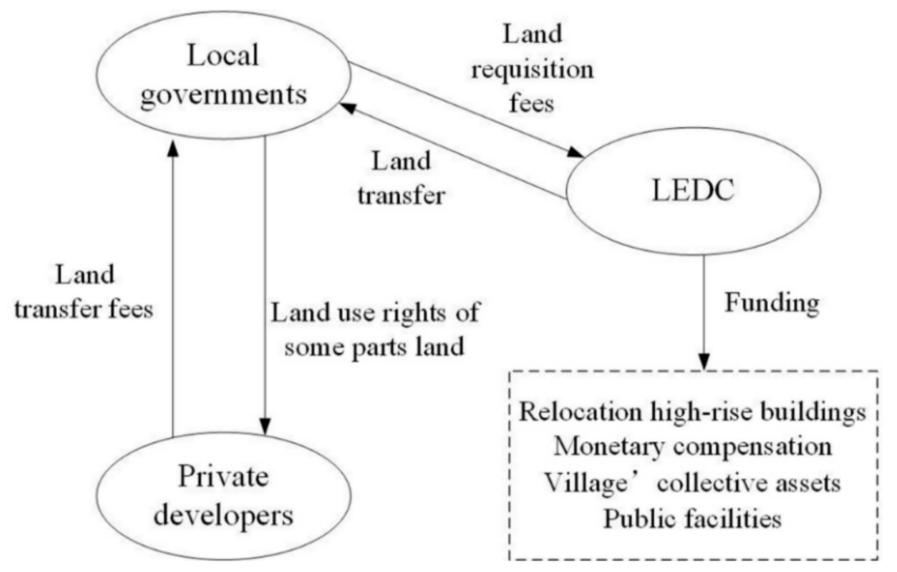

Figure 2. Institutional arrangement of village renewal in Liede Village.

According to the interviewees, although several households did not support the unified compensation scheme and were reluctant to move out of their houses with the expectation of 
gaining higher compensation, the conflicts were finally settled by court arbitration. Under this institutional arrangement, the project has run very smoothly as the vast majority of villagers trust the LEDC, which represents the interests of the whole village, compared with the local government and a private developer. On 15 October 2007, all the residents had evacuated from their houses with temporary compensation of RMB $25 / \mathrm{m}^{2}$ per month for them to rent a home until they move into their new relocated apartment. The construction of relocated high-rise buildings began in January 2008 . After around 33 months, all the residents returned to the 37 relocated buildings in September 2010 by means of a public lottery (yaozhu).

After completion of the project, the greening rate had been increased to $30 \%$, while the building density decreased from $60 \%$ to $28.1 \%$. The plot ratio is now around 5.3. The public facilities are largely improved with additional municipal roads of over $10,000 \mathrm{~m}^{2}$. In addition, the LEDC also constructed several five-star hotels, occupying a land area of $33,200 \mathrm{~m}^{2}$ as a collective asset to ensure the sustainable long-term profit for the villagers. Accordingly, the current rental income (around RMB $90 / \mathrm{m}^{2}$ ) of the villagers has been largely increased to about eight times more than before (around RMB $10-20 / \mathrm{m}^{2}$ ). The village security is largely improved due to urban gentrification so that the immigrants in the villages are highly qualified individuals. The renewal process also enforces the principle of protection and inheritance of traditional culture. Longmu Temple was built as a copy of the original one. Five different ancestral halls for different tribes, retaining the original building style, were built to substitute for the widely dispersed old ones.

\subsection{Outsourced Institutional Arrangement in Yangji Village}

Yangji Village has a history of around 960 years, originally founded in the Bei Song Dynasty. It is located in the eastern part of the Yuexiu district in Guangzhou, where around 1479 households live. In 1986, Yangji Village started to be transformed into the autonomous mass organizations, substituting the resident status and Yangji Economic Association (YJEA) for the villager status and village committees, respectively. Thus, the role of the YJEA is responsible for the economic development of the village based on the collective assets. The newly established organization of the residents' committee is responsible for managing daily affairs. In response to the guidelines for the redevelopment of the "three olds" (old urban areas, factories, and villages) initiated by the Guangzhou government in 2009 [51], the YJEA organized a mobilization meeting to urge the villagers to participate in the renewal project. To pool the funds to renew the village, Yangji Village allowed private developers to fund and implement the renewal project by forfeiting one parcel land in the village. Under this institutional arrangement, the YJEA was not fully empowered. They just represented all the affected villagers, negotiating with the private developer to discuss the relocation and compensation schemes, housing type, housing design, and public facilities after collecting suggestions from the villagers.

On 18 January 2011, the land use rights of an area of land comprising 62,808 $\mathrm{m}^{2}$ were transferred to the private developer Fuli, the only competitor, by public auction for RMB 473 million in land transfer fees. In addition, village renewal costs amounting RMB 1.88 billion were annexed to the contract for transferring state-owned land [59]. Under this institutional arrangement, Fuli took a very active role during the village renewal process. The in-kind compensation (exchange) was based on the legal property area approved by the government when the villagers applied to build their houses before the renewal project was initiated. To proceed with the project, the additional illegal floors were compensated with an amount of around RMB $800-2000 / \mathrm{m}^{2}$, based on the material used in the buildings. Moreover, temporary compensation of RMB $30 / \mathrm{m}^{2}$ per month was also provided to enable the affected villagers to rent an apartment when evacuated from their houses. In addition, each household could get RMB 10,000 as an incentive if they agreed to a contract before 30 May 2010. Yet, the project did not run as smoothly as Fuli expected. Despite $99 \%$ of the houses being demolished within two months of the starting date of 1 July 2010, it took roughly 37 months to demolish the last $1 \%$ of the houses. Villagers resisted and conflicts broke out when the private developer attempted to forcibly demolish the last several houses, delaying the demolition. And even though villagers who had already moved 
tried to persuade the householders who were hanging on to evacuate their houses in order to expedite the project, this also failed, with internal conflicts arising. The final householders intended to protect their property rights, while those who had already moved out wanted to move into their relocated high-rise buildings as soon as possible, especially elderly couples who did not want to die outside their village. In the end, the YJEA represented the interests of $99 \%$ of the householders, so the remaining $1 \%$ of householders were taken to court, which decided that the holdout houses would be forcibly demolished. A tragedy occurred, however, when one member of a family killed herself by jumping off of her house. This was because she was offered little monetary compensation since her house was deemed illegal due to the absence of a property certificate. Several other households that had held out finally agreed to move after Fuli made a compromise with them. In sum, the institutional arrangement of the village in Yangji is shown in Figure 3. Under such an institutional arrangement, the private developer played a more active role in the redevelopment process. On the other hand, the YJEA represented the interests of its constituent villagers to negotiate with the private developer in order to achieve a consensus on the redevelopment scheme. Obviously, the YJEA had the power to influence the policy making of compensation and relocation. The government took the same role in land transaction as in the Liede Village case.

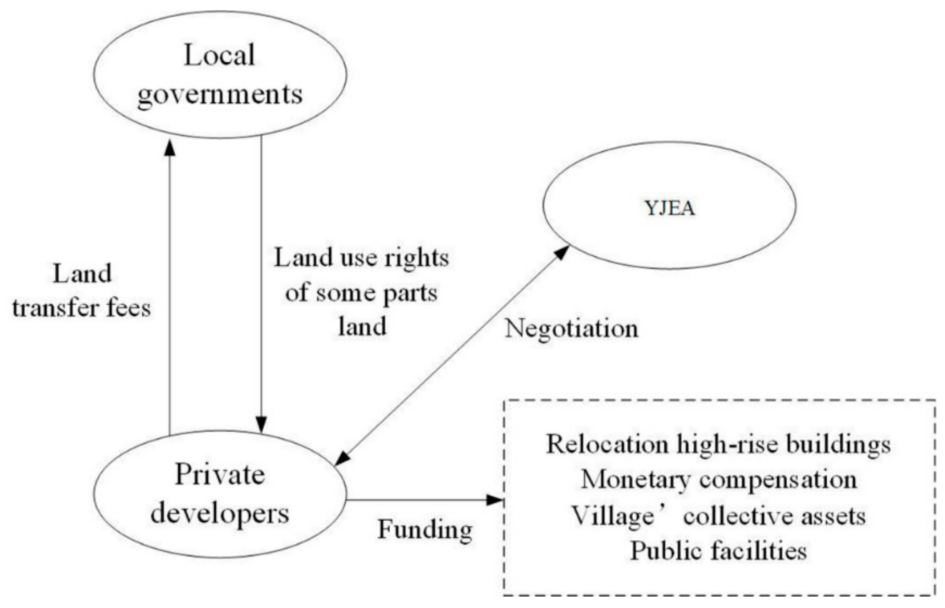

Figure 3. Institutional arrangement of village renewal in Yangji Village.

As claimed by the interviewees, the villagers who had moved out happily were relocated to the high-rise buildings after holding a lottery in May 2016. The newly constructed developments included 15 relocated high-rise buildings from 36 to 42 stories with a construction area of $374,200 \mathrm{~m}^{2}$ in total. After the renewal project, the plot ratio became 5.16, and the land use efficiency was largely improved. The extra land was used to build a kindergarten, primary school, public garden, and fitness centers, among other things, in the village. Since Yangii Village has a long history with many historical relics, like Yuxugong serving as the municipal cultural relics protection unit in Guangzhou, with a construction area of $317 \mathrm{~m}^{2}$, the renewal project kept it as it was. To improve the land use efficiency, four new ancestral halls that retained the original building style, for four different tribes (e.g., the Yao's, Qin's, Li's, and Liang's families), were built to substitute for the widely dispersed old ones. They are located near the Yuxugong. Since the village renewal project, the living environment is improving, and the rental income of the villagers is around 10 times that of before. Though there is no land left in the village to develop the collective economy, the innovative design of the bottom three stories of each relocated high-rise building were designed for commercial space. Apart from this, there are also three levels of underground parking under each building. These two sources of rental income serve as the collective assets that can continuously produce profits for all the villagers.

As for cost recovery, Fuli used the transferred land to build high-rise commercial buildings. The total construction area was $273,800 \mathrm{~m}^{2}$, including four luxurious accommodations from 44 to 49 stories, one office building with 50 stories, and one hotel with 38 stories. By selling accommodations 
or leasing the office space or hotel rooms in the market, Fuli can recoup their costs and pursue profit in the long run.

\subsection{Partnership Institutional Arrangement in Linhe Village}

Linhe Village has a history of around 450 years, is located in the core of the central business district (CBD) in the northern part of the Tianhe district, and has around 700 households. It is in a desirable location less than $200 \mathrm{~m}$ from the East railway station. In 1998, Linhe Village abandoned the village committees and established the Linhe Runyang Economic Development Company (LREDC), Guangzhou, China. Later, the LREDC submitted a village renewal plan to the local government for approval. In 2002, the LREDC designed a renewal scheme for the old village. It took until 2008 for the local government to agree with the feasibility of the renewal project. In November, the compensation and relocation schemes of Linhe Village were first announced publicly in 2009, in order to solicit suggestions from the local villagers. After holding eight meetings with the villagers, $93 \%$ of them agreed to the renewal scheme. This rate exceeded the minimum threshold of $90 \%$ to implement the renewal project. After negotiating with several private developers starting in 2004, the LREDC finally chose Sun Hung Kai Properties Limited (SHK) from Hong Kong and contracted with them to cooperate on the village renewal project. This was the first experimental practice in which the villagers directly cooperated with private developers and with minimum interference from the local government.

The Linhe Village renewal project occupied an area of around $65,000 \mathrm{~m}^{2}$, with a total construction area of about $400,000 \mathrm{~m}^{2}$. The northern part of the village's land was planned as the relocation area, including six relocated high-rise buildings with 49 stories and one office building. During this process, all the funds were provided by SHK, including the monetary compensation fees of RMB $1100 / \mathrm{m}^{2}$ for illegal houses, temporary relocation fees of RMB $26 / \mathrm{m}^{2}$ per month to rent an apartment when villagers evacuated their houses, and construction fees for the relocated high-rise buildings. As for cost recovery, the land located in the south of the village was planned for developing commercial buildings to pursue long-term profit, including seven high-rise residential buildings and one apartment, with a construction area of around $185,000 \mathrm{~m}^{2}$. SHK owns $70 \%$ of the shares of these commercial buildings, while the LREDC owns the other $30 \%$. As opposed to the practice of selling the land outright to raise funds for the renewal of the village, Linhe Village adopted the method of contracting directly with SHK to disperse the venture risk together. The institutional arrangement of the village renewal in Linhe Village is shown in Figure 4.

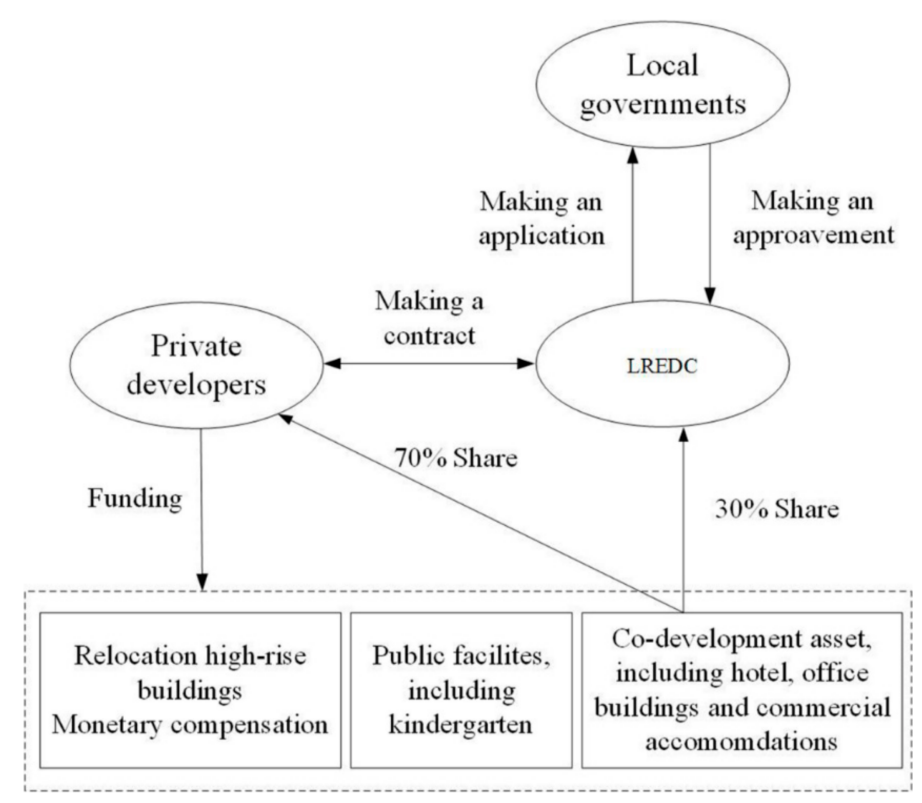

Figure 4. Institutional arrangement of village renewal in Linhe Village. 


\subsection{Comparison of the Three Projects}

Table 2 summarizes the key characteristics of the three urban village renewal projects under investigation. Among the three projects, Liede Village project had the largest scale in terms of the number of households affected. Although a legal entity was formed in all three cases to administrate and manage the village renewal project, the decision-makers or controllers are different. Original villagers had a say in the renewal project of Liede Village while not possessing fully decision-making power in Yangii Village project. In Linhe Village, original villagers partnered with private developers in form of a joint venture. Although the villagers held a minority share of the joint venture, their views still had some bearings on the project design and delivering.

Table 2. Key characteristics of the three urban village renewal projects.

\begin{tabular}{|c|c|c|c|}
\hline Characteristic & Liede Village & Yangji Village & Linhe Village \\
\hline No. of affected households & Over 3000 & Around 1480 & Around 700 \\
\hline Institutional arrangement & Bottom-up approach & Developer-led approach & Partnership approach \\
\hline Source of finance & $\begin{array}{l}\text { Private developers } \\
\text { (via local governments) }\end{array}$ & Private developers & Private developers \\
\hline
\end{tabular}

\section{Discussion}

As far as the decision making mechanism is concerned, all three cases under investigation can come under the category of "bottom-up approach", because the three projects were initiated by the respective village committees. However, in each case, the roles played by the village committees, private developers and governments in the redevelopment process were different so there were three different forms of institutional arrangement. From a neo-institutional economics perspective, the institutional arrangements have a direct impact on the levels of transaction costs. Yet it is still unknown whether it applies to the urban village renewal process. This study tries to address this research gap. Transaction costs began to make sense with the existence of the firm [60]. Ronald Coase argues that transaction costs are essential for us to understand the working of the economic system, to analyze many of its problems in a useful way, or to have a basis for determining a policy [61]. Despite the voluminous literature that relates to the transaction, theoretical consensus on its definition has still not been reached. For instance, Harold Demsetz holds that transaction costs are the costs of exchanging ownership titles [62], while Yoram Barzel argues that they are the costs associated with the transfer, capture, and protection of rights [63]. Given the complexity involved in considering all the transaction costs occurred in the redevelopment process, this study puts forward an alternative method to measure some given outcomes. Phrased differently, higher transaction costs are normally demonstrated by certain project outcomes such as longer project durations and higher levels of conflict. Generally, it is assumed that the lower the transaction cost, the smoother and more efficient the development process will be. As for the conflicts, they can be attributed to transaction costs associated with incomplete information, bounded rationality and uncertainties. Thus, in this study, we mainly use the length of project duration and levels of conflict as the scales to measure the transaction costs that occurred in the village renewal process.

In the three selected cases, three different institutional arrangements were utilized with different time frames for demolition and the total project, as shown in Figure 5. We can see that it took around three months to demolish the whole village in both Liede and Linhe, while it took around 37 months in Yangji. The length of time for demolition directly reflects the degree of consensus between the affected villagers and the renewal executor. Since there existed several householders who held out in Yangii and did not agree to evacuate their houses, it delayed the duration of the demolition. In terms of total project duration, the Liede Village renewal took the shortest time even though demolition took the same amount of time as in Linhe Village. 

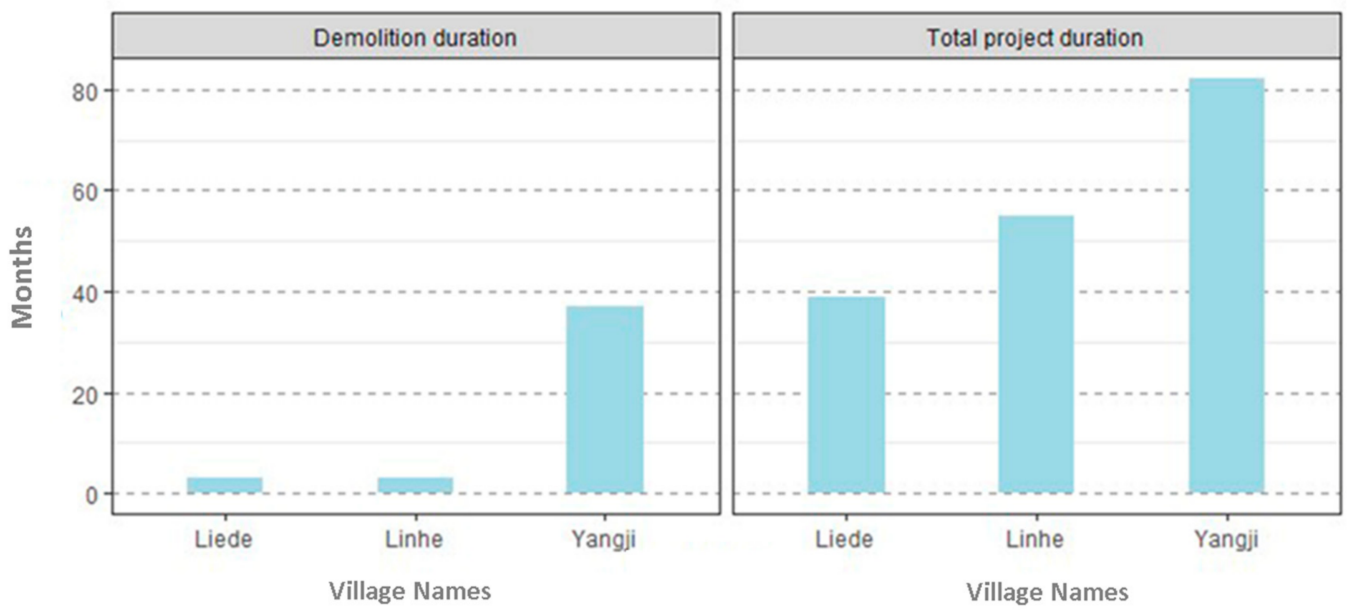

Figure 5. Demolition durations and total project durations of the three urban villages.

In terms of conflict levels, all three renewal villages experienced holdout problems which seem a common phenomenon during the urban redevelopment project. The disparities are reflected by the levels of conflict and how each was settled. In Liede Village, the LEDC chose to utilize lawsuits to settle the conflict and then forcibly and peacefully demolish the last several houses. In Linhe Village, the LREDC chose to negotiate several times with those holding out and compromise with some of the householders' requirements. But in Yangji Village, no compromise was reached between the private developers and last remaining householders. In that situation, the YJEA also sued these householders in order to get their relocated high-rise buildings as soon as possible. As mentioned, one of the remaining householders ultimately committed suicide when the YJEA forcibly demolished the villager's houses.

With the findings of this study, we can answer the research question. Institutional arrangements significantly affect the outcomes of urban village redevelopment projects. From the research findings, some important policy implications can be drawn. It is important for the governments or other actors to look for institutional frameworks with lower transaction costs to facilitate redevelopment of urban villages. One possible way to engage the stakeholders, particularly the local communities, in a renewal project with a lower transaction costs is the application of mobile information and communication technologies [64,65]. Moreover, to reduce the levels of conflict in the urban renewal process, resort can be made to the approach of "planning mediation". Planning mediation is popular in Scandinavian countries and Australia as a conflict management technique for sensitive or large-scale projects [66,67]. This approach can reduce the occurrence of conflicts, smooth the conflict resolution process and allow arrival at a decision which is acceptable to most (if not all) interested stakeholders.

\section{Conclusions}

In sum, this study attempts to argue that the institutional arrangement of village renewal projects has a direct relationship to the transaction costs in terms of project duration and levels of conflict. All three urban villages had relatively good locations. Prior to the village renewal project, the number of indigenous households in Liede, Yangji, and Linde was 3167, 1479, and 703, respectively. Yet Liede took the shortest time to complete the project, indicating the highest degree of time-efficiency of the redevelopment process. With different degrees of participation by private developers, the conflicts were also different. It is hard to deny the impacts that the institutional arrangement exerts on transaction costs in terms of project duration and conflicts. Under different institutional arrangements, the costs of acquiring information are different. Although institutions do not solve all problems, if we explore some efficient ones, they can help the project run smoothly and reach win-win outcomes. The cases delineated above cannot explain all the phenomena, but they can inspire the governments to alter the existing institutions when facing increasing transaction costs. Perhaps, local governments or developers can explore ways to lower the transaction costs of information sharing and exchange. 
Author Contributions: The authors' individual contributions are outlined as follows: conceptualization, D.Y. and Y.Y.; methodology, D.Y. and Y.Y.; investigation, D.Y.; formal analysis, D.Y.; supervision, Y.Y.; manuscript writing, D.Y., Y.Y., H.B., Y.L. and T.L.; Final approval of the manuscript, D.Y., Y.Y., H.B., Y.L. and T.L.

Funding: This research received no external funding.

Conflicts of Interest: The authors declare no conflict of interest.

\section{References}

1. National Bureau of Statistics of China. China County Statistical Yearbook; China Statistics Press: Beijing, China, 2016.

2. Tian, L.I. The Chengzhongcun land market in China: Boon or bane? A perspective on property rights. Int. J. Urban Reg. Res. 2008, 32, 282-304. [CrossRef]

3. Kochan, D. Placing the urban village: A spatial perspective on the development process of urban villages in contemporary China. Int. J. Urban Reg. Res. 2015, 39, 927-947. [CrossRef]

4. Zhang, L.; Zhao, S.X.; Tian, J.P. Self-help in housing and chengzhongcun in China's urbanization. Int. J. Urban Reg. Res. 2003, 27, 912-937. [CrossRef]

5. Hao, P.; Sliuzas, R.; Geertman, S. The development and redevelopment of urban villages in Shenzhen. Habitat Int. 2011, 35, 214-224. [CrossRef]

6. Lin, Y.; Hao, P.; Geertman, S. A conceptual framework on modes of governance for the regeneration of Chinese 'villages in the city'. Urban Stud. 2014, 52, 1774-1790. [CrossRef]

7. Wu, F.; Zhang, F.; Webster, C. Informality and the development and demolition of urban villages in the Chinese peri-urban area. Urban Stud. 2013, 50, 1919-1934. [CrossRef]

8. Ding, C. Policy and praxis of land acquisition in China. Land Use Policy 2007, 24, 1-13. [CrossRef]

9. Zheng, S.; Long, F.; Fan, C.C.; Gu, Y. Urban villages in China: A 2008 survey of migrant settlements in Beijing. Eurasian Geogr. Econ. 2009, 50, 425-446. [CrossRef]

10. Liu, Y.; He, S.; Wu, F.; Webster, C. Urban villages under China's rapid urbanization: Unregulated assets and transitional neighbourhoods. Habitat Int. 2010, 34, 135-144. [CrossRef]

11. Bagaeen, S.G. Redeveloping former military sites: Competitiveness, urban sustainability and public participation. Cities 2006, 23, 330-352. [CrossRef]

12. He, S.; Liu, Y.; Wu, F.; Webster, C. Social groups and housing differentiation in China's urban villages: An institutional interpretation. Hous. Stud. 2010, 25, 671-691. [CrossRef]

13. He, X. Maintaining stability by law: Protest-supported housing demolition litigation and social change in China. Law Soc. Inq. 2014, 39, 849-873. [CrossRef]

14. Wang, Y.P.; Wang, Y.; Wu, J. Urbanization and informal development in China: Urban villages in Shenzhen. Int. J. Urban Reg. Res. 2009, 33, 957-973. [CrossRef]

15. Zhu, J. From Land use right to land development right: Institutional change in China's urban development. Urban Stud. 2004, 41, 1249-1267. [CrossRef]

16. Barnes, K.; Waitt, G.; Gill, N.; Gibson, C. Community and nostalgia in urban revitalisation: A critique of urban village and creative class strategies as remedies for social 'problems'. Aust. Geogr. 2006, 37, 335-354. [CrossRef]

17. Wu, F. How neoliberal is China's reform? The origins of change during transition. Eurasian Geogr. Econ. 2010, 51, 619-631. [CrossRef]

18. Qian, J.; He, S.; Liu, L. Aestheticisation, rent-seeking, and rural gentrification amidst China's rapid urbanisation: The case of Xiaozhou Village, Guangzhou. J. Rural Stud. 2013, 32, 331-345. [CrossRef]

19. William, O.E. The new institutional economics: Taking stock, looking ahead. J. Econ. Lit. 2000, 38, 595-613. [CrossRef]

20. Nabi, M.K.; Nugent, J.B. The new institutional economics and its applicability to development. World Dev. 1989, 17, 1333-1347. [CrossRef]

21. North, D.C. Institutions, Institutional Change and Economic Performance; Cambridge University Press: New York, NY, USA, 1990.

22. Searle, J.R. What is an institution? J. Inst. Econ. 2005, 1, 1-22. [CrossRef]

23. North, D.C. Institutions, ideology, and economic performance. Cato J. 1991, 11, 477-488.

24. Needham, B. Planning, Law and Economics: The Rules We Make for Using Land; Routledge: London, UK, 2006. 
25. Buitelaar, E.; Lagendijk, A.; Jacobs, W. A theory of institutional change: Illustrated by Dutch city-provinces and Dutch land policy. Environ. Plan. A 2007, 39, 891-908. [CrossRef]

26. Galvin, T.L. Examining institutional change: Evidence from the founding dynamics of US health care interest associations. Acad. Manag. J. 2002, 45, 673-696.

27. Caldarice, O.; Cozzolino, S. Institutional contradictions and attempts at innovation: Evidence from the Italian urban facility planning. Eur. Plan. Stud. 2019, 27, 68-85. [CrossRef]

28. Dacin, M.T.; Goodstein, J.; Scott, W.R. Institutional theory and institutional change: Introduction to the special research forum. Acad. Manag. J. 2002, 45, 45-56. [CrossRef]

29. Zhou, Q. Urban-Rural in China: First Volume; China CITIC Press: Beijing, China, 2013.

30. Ho, P. Who owns China's land? Policies, property rights and deliberate institutional ambiguity. China $Q$. 2001, 166, 394-421. [CrossRef]

31. Zhou, Q. Urban-Rural in China: Second Volume; China CITIC Press: Beijing, China, 2014.

32. Liu, R.; Wong, T.; Liu, S. Peasants' counterplots against the state monopoly of the rural urbanization process: Urban villages and 'small property housing' in Beijing, China. Environ. Plan. A 2012, 44, 1219-1240. [CrossRef]

33. Chan, E.H.; Kwok, G. Foreign participation in housing development in Mainland China: Legal concerns on property ownership. Rev. Urban Reg. Dev. Stud. 1999, 11, 154-167. [CrossRef]

34. Zhang, L.; Ye, Y.; Chen, J. Urbanization, informality and housing inequality in indigenous villages: A case study of Guangzhou. Land Use Policy 2016, 58, 32-42. [CrossRef]

35. Brandt, L.; Huang, J.; Li, G.; Rozelle, S. Land rights in rural China: Facts, fictions and issues. China J. 2002, 47, 67-97. [CrossRef]

36. Wang, H.; Tong, J.; Su, F.; Wei, G.; Tao, R. To reallocate or not: Reconsidering the dilemma in China's agricultural land tenure policy. Land Use Policy 2011, 28, 805-814. [CrossRef]

37. Zhao, P. An 'unceasing war' on land development on the urban fringe of Beijing: A case study of gated informal housing communities. Cities 2017, 60, 139-146. [CrossRef]

38. Xu, Y.; Tang, B.; Chan, E.H.W. State-led land requisition and transformation of rural villages in transitional China. Habitat Int. 2011, 35, 57-65. [CrossRef]

39. Zhang, Q.F.; Donaldson, J.A. China's agrarian reform and the privatization of land: A contrarian view. J. Contemp. China 2013, 22, 255-272. [CrossRef]

40. Zou, X.; Oskam, A.J. New compensation standard for land expropriation in China. China World Econ. 2017, 15, 107-120. [CrossRef]

41. Choy, L.H.T.; Lai, Y.; Lok, W. Economic performance of industrial development on collective land in the urbanization process in China: Empirical evidence from Shenzhen. Habitat Int. 2013, 40, 184-193. [CrossRef]

42. Xie, Q.; Parsa, A.G.; Redding, B. The emergence of the urban land market in China: Evolution, structure, constraints and perspectives. Urban Stud. 2002, 39, 1375-1398. [CrossRef]

43. Zhao, B. Land expropriation, protest, and impunity in rural China. Focaal 2009, 54, 97-105. [CrossRef]

44. Cao, G.; Feng, C.; Tao, R. Local 'land finance' in China's urban expansion: Challenges and solutions. China World Econ. 2008, 16, 19-30. [CrossRef]

45. He, S. Two waves of gentrification and emerging rights issues in Guangzhou, China. Environ. Plan. A 2012, 44, 2817-2833. [CrossRef]

46. Zhu, J.; Guo, Y. Fragmented peri-urbanisation led by autonomous village development under informal institution in high-density regions: The case of Nanhai, China. Urban Stud. 2013, 51, 1120-1145. [CrossRef]

47. Elklit, J. The Chinese village committee electoral system. China Inf. 1997, 11, 1-13. [CrossRef]

48. Bao, H.; Peng, Y. Effect of land expropriation on land-lost farmers' entrepreneurial action: A case study of Zhejiang Province. Habitat Int. 2016, 53, 342-349. [CrossRef]

49. Wong, S.W. Urbanization as a process of state building: Local governance reforms in China. Int. J. Urban Reg. Res. 2015, 39, 912-926. [CrossRef]

50. Li, L. A Study on the Formation and Reform Mechanism of Villages-in-the-City in Guangzhou City; Sun Yat-sen University: Guangzhou, China, 2001.

51. Ye, L. Urban regeneration in China: Policy, development, and issues. Local Econ. 2011, 26, 337-347. [CrossRef]

52. Gong, J.; Chen, W.; Liu, Y.; Wang, J. The intensity change of urban development land: Implications for the city master plan of Guangzhou, China. Land Use Policy 2014, 40, 91-100. [CrossRef] 
53. Guangzhou International. Administrative Regions and Population. Available online: http://english.gz.gov. cn/gzgoven/s3616/201508/849fdfb0543b4fc5bbaadb967aa0fa2f.shtml (accessed on 29 April 2019).

54. Guangzhou Statistics Bureau. 2018 Population Scale and Distribution in Guangzhou. Available online: http://www.gzstats.gov.cn/gzstats/tjgb_qtgb/201902/da07f05ce86a41fd97415efec5637085.shtml (accessed on 29 April 2019).

55. Lai, S.; Wu, J. Speed and benefit: Guangzhou 'three old' redevelopment strategies for new urbanization. Planners 2013, 5, 36-41.

56. Buckingham, W. Uncorking the neoliberal bottle: Neoliberal critique and urban change in China. Eurasian Geogr. Econ. 2017, 58, 297-315. [CrossRef]

57. Li, L.H.; Lin, J.; Li, X.; Wu, F. Redevelopment of urban village in China-A step towards an effective urban policy? A case study of Liede Village in Guangzhou. Habitat Int. 2014, 43, 299-308. [CrossRef]

58. Cheng, Z. The changing and different patterns of urban redevelopment in China: A study of three inner-city neighborhoods. Community Dev. 2012, 43, 430-450. [CrossRef]

59. Wei, J. The law reviews on the listing to sell public land by concluding the base prices of the Yangji Cun modifying. Superv. Test Cost Constr. 2011, 4, 78-79.

60. Coase, R.H. The nature of the firm. Economica 1937, 4, 386-405. [CrossRef]

61. Coase, R.H. Blackmail. Va. Law Rev. 1988, 74, 655-676. [CrossRef]

62. Demsetz, H. The cost of transacting. Q.J. Econ. 1968, 82, 33-53. [CrossRef]

63. Barzel, Y. Economic Analysis of Property Rights; Cambridge University Press: Cambridge, UK, 1989.

64. Houghton, K.; Miller, E.; Foth, M. Integrating ICT into the planning process: Impacts, opportunities and challenges. Aust. Plan. 2014, 51, 24-33. [CrossRef]

65. Hobololo, T.S.; Mawela, T. Exploring the use of mobile phones for public participation in the Buffalo City Metropolitan Municipality. Agris On-Line Papers. Econ. Inform. 2017, 9, 57-68. [CrossRef]

66. Røsnes, A.E. Regulatory power, network tools and market behaviour: Transforming practices in Norwegian urban planning. Plan. Theory Pract. 2005, 6, 35-51. [CrossRef]

67. Peltonen, L.; Sairinen, R. Integrating impact assessment and conflict management in urban planning: Experiences from Finland. Environ. Impact Assess. Rev. 2010, 30, 328-337. [CrossRef]

(C) 2019 by the authors. Licensee MDPI, Basel, Switzerland. This article is an open access article distributed under the terms and conditions of the Creative Commons Attribution (CC BY) license (http://creativecommons.org/licenses/by/4.0/). 